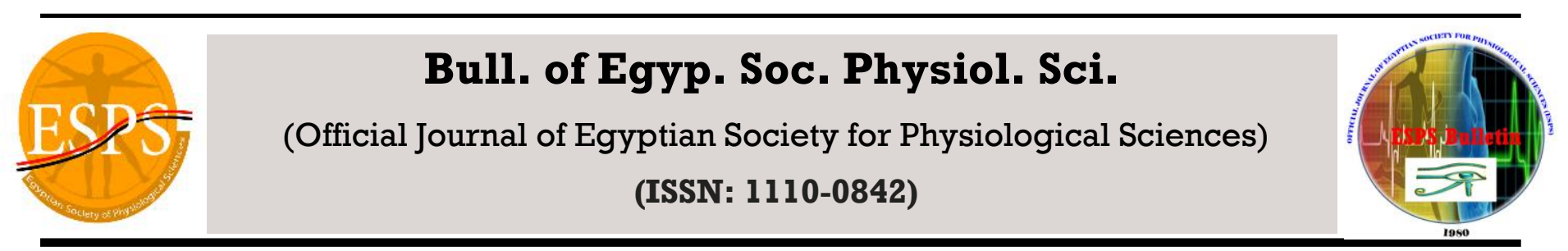

\title{
Vitamin E Ameliorates Short-Term Exercise-Induced Damage in Kidney and Skeletal Muscle of Male Albino Rats
}

\author{
Ghada S. Mahmoud \\ Department of Physiology, Faculty of Medicine, Assiut University, Assiut, Egypt
}

Received: Oct $7^{\text {th }} 2014$, Accepted: Dec $26^{\text {th }} 2104$ Available online: $1 \mathrm{Jan}$, 2015

\section{Keywords}

- Swimming

- Tumor necrosis factor-alpha $(\mathrm{TNF}-\alpha)$

- interferon gamma (INF- $\gamma$ ),

- $\mathrm{C}$ reactive protein (CRP)

- Vitamin E

- Muscle

- Kidney.

\section{Abstract}

Objective. Short term exhausting exercise increases the formation of harmful reactive oxygen species. We evaluated effect of vitamin E supplementation prior to swimming on circulating inflammatory markers, muscle endothelial nitric oxide synthase (eNOS) expression, functional and structural changes of muscle and kidney of rats. Methods. 24 male albino rats were divided into 3 groups: (C) control group (not submitted to exercise stress), (S) exercise stress group, and (SE) exercise stress and vitamin E group. The rats from SE group were treated with gavage administration of vitamin $\mathrm{E}\left(50 \mathrm{mg} \cdot \mathrm{kg}^{-1}\right)$ prior to swimming. The animals from $\mathrm{S}$ and $\mathrm{SE}$ groups were submitted to bouts of swimming exercise stress for 1 hour daily for a week. Results. We found that swimming stress significantly elevated plasma tumor necrosis factor-alpha (TNF- $\alpha$ ), interferon gamma (INF- $\gamma$ ) and $\mathrm{C}$ reactive protein (CRP). Exercise stress caused significant decrease in relative kidney weight, Total body weight (TBW), plasma urea and creatinine levels $30 \mathrm{~min}$. after the last session of exercise. However, it significantly increased urea to creatinine ratio and caused considerable damage in kidney cells as revealed by histological examinations. Microscopic examination of muscle samples showed hypervascularity, raised nuclear number, splitting of muscle fibers, and central location of nuclei. Administration of vitamin $\mathrm{E}$ for seven consecutive days before the exposure to exercise significantly decreased TNF-alpha, INF-gamma and didn't change CRP level. Vitamin E supplementation decreased urea to creatinine ratio, increased TBW, increased endothelial nitric oxide synthase (eNOS) expression and ameliorated the structural changes that occurred in the muscle and kidney. Conclusion. Present study revealed that vitamin E supplementation has promising protective role against exercise-induced elevation of cytokines, muscular damage as well as dehydration and potential renal damage.

Corresponding author: Ghada S. Mahmoud, Medical Physiology Department, Faculty of Medicine, Assiut University, Assiut,

Egypt Mail: ghadaszam@gmail.com, Mobile: +201069651669 


\section{INTRODUCTION}

Swimming is a form of minor traumatic exercise for animals and has been commonly used to elucidate the physiologic and molecular responses of the muscle to exercise stress. ${ }^{1,} 2$ Skeletal muscle is a powerful generator of some myokines, especially interleukin-6 (IL-6) ${ }^{3}$. Evidences suggest that regular exercise antagonizes inflammation through modulating cytokines. ${ }^{3}$ Previous studies proved that regular exercise training reduces inflammatory markers; tumor necrosis factor-alpha (TNF- $\alpha$ ), CRP, and IL-6 levels and increases anti-inflammatory markers such as IL-4 and IL-10. ${ }^{4}$ However, the effect of regular well accustomed exercise versus acute unaccustomed exercise on inflammatory cytokines appears to be contradictory. One study reported rise of inflammatory cytokines with acute bouts of exercise. ${ }^{5}$ TNF- $\alpha{ }^{4}$ and IFN $\gamma^{6}$ have antiviral and immune-regulatory functions. C-reactive protein is an acute-phase protein that is elevated in response to inflammation. ${ }^{7}$

It has been reported by several studies that skeletal muscles during intense prolonged contraction generate free radicals that damage cellular constituents. ${ }^{8,9}$ It is also reported that low-to-moderate levels of oxidants are capable of controlling gene expression, cell signaling pathways, and modulating force production in the skeletal muscle. ${ }^{10,11}$ Nitric oxide (NO) is one of the primary free radicals generated in the cells. ${ }^{12}$ Kidney is considered as one of the important organs affected by exercise. Estimation of the plasma urea concentration is common screening test for renal failure. However, blood urea concentration is elevated significantly in advanced renal injury. ${ }^{13}$ Blood urea may be elevated for reasons other than glomerular failure, therefore, estimating plasma creatinine concentration and calculating urea to creatinine ratio helps to distinguish the cause of prerenal failure. ${ }^{14}$

Alpha-tocopherol has been reported to affect lymphocyte number and circulating levels of cytokines. ${ }^{5}$ It has been suggested that vitamin E administration in aged people improves immune response by modulating cytokine production. $^{15}$ However, previous studies showed conflicting outcomes for the effect of $\alpha$-tocopherol on inflammatory mediators. ${ }^{16}$ The ability of vitamin $\mathrm{E}$ to keep functional as well as structural integrity of normal kidney ${ }^{17}$ and skeletal muscle have been reported by previous studies. ${ }^{18}$ Moreover, role of vitamin $\mathrm{E}$ in regulating nitric oxide $(\mathrm{NO})$ production and endothelial nitric oxide (eNOA) synthase activity has been shown by previous studies. ${ }^{19}$ Therefore, the purpose of this study is to elucidate the effects of acute unaccustomed swimming versus swimming and vitamin $\mathrm{E}$ supplementation on plasma levels of inflammatory cytokines, functional, structural 
changes in kidney and skeletal muscle as well as eNOS expression in skeletal muscle.

\section{Materials and Methods}

Drugs and chemicals

Vitamin E $\left(50 \mathrm{ml} \mathrm{kg}{ }^{-1}\right.$ S.G. capsules antioxidant manufactured by Safe Pharma for Pharmaco Pharmaceuticals, Egypt). One capsule containing $1 \mathrm{gm}$ is dissolved in $20 \mathrm{ml}$ olive oil. $^{20}$ Rat TNF-alpha ELIZA Kit (K0331196) Koma Biotech INC. AVITEX CRP (Ref OD073/OD023/ OD023/E) Omega Diagnostics. Rat IFN-gamma ELIZA Kit. (K0331209) Koma Biotech INC. CreatinineKit Jaffe. Colorimetric - kinetic (Diamond Diagnostics, 333 Fiske St, Holliston, MA 01746, United States, REF 2 x 100 ml). UreaKit S 180 (Biomerieux sa, 69280 Marcyl'Etoile/ France, REF 61912). Nitric Oxide Synthase, endothelial (eNOS), Rabbit Polyclonal Antibody (Thermo Scientific, South San Francisco, California, USA).

\section{Animal preparation and experimental} approach

Experiments were performed on a total of 24 male albino rats weighing 90-120 grams. Animals were obtained from the animal's house facility, Faculty of Medicine, Assiut University, Assiut, Egypt. Two days before experimentation, the animals were kept in the laboratory at Department of Medical Physiology for accommodation in the condition of normal light/ dark cycle with free access to standard rat chow and tap water. The experiments were carried out according to the protocol approved by the Local Ethical Committee of the Faculty of Medicine, Assiut University in accordance with the ethical guidelines for scientific research in conscious animals. Animals were randomized into three groups: $(\mathrm{C})$ the control group $(\mathrm{n}=8)$, in which rats received $1 \mathrm{ml}$ of water by gavage for seven consecutive days; (S) exercise stress group $(\mathrm{n}=8)$, in which rats received $1 \mathrm{ml}$ of water by gavage for seven consecutive days and submitted to exhaustive exercise stress and; (SE) exercise stress + Vitamin E group (n $=8$ ), in which rats were treated with gavage administration of $1 \mathrm{ml}$ of Vitamin $\mathrm{E}$ (50 $\mathrm{mg} / \mathrm{kg}$, alpha tocopherol) for seven consecutive days and submitted to exhaustive exercise stress. Rats were forced to swim for one hour without a load until exhaustion daily for 7 consecutive days. ${ }^{21}$ The swimming tank was (100 cm long, $50 \mathrm{~cm}$ wide, $80 \mathrm{~cm}$ deep) containing water maintained at $30^{\circ} \mathrm{C}$. When the animal stop swimming and sink for 10 seconds, it was removed from the water for a min. and returned back to continue swim for an hour, The depth of the tank prevented the animals from resting their tails on the bottom of the tank while swimming. Swimming was selected to avoid muscle trauma caused by other methods of forced exercise as prolonged running or exercise-stimulated electric shock. $^{22}$ 


\section{Laboratory Methods}

Half an hour after the last session of swimming exercise stress, the animals were anesthetized by ether inhalation and blood samples are collected from the eyes into heparinized tubes. The plasma were isolated and stored at $-20^{\circ} \mathrm{C}$ until use. Plasma urea level was detected using Urea-Kit S using urease- modified Berthelot reaction (end point enzymatic determination), blood urea nitrogen (BUN) was calculated using the following formula; BUN (mg/dl) = urea(mg/dl)/2.14. ${ }^{23}$ Plasma creatinine level using Jaffe Colorimetric-kinetic at 492nm, C reactive protein $(\mathrm{CRP})$, tumor necrosis factor $\alpha$ (TNF- $\alpha$ ), gamma interferon (INF- $\gamma$ ) using enzyme-linked immunosorbent assay (ELISA) kits following the manufacturer's instructions.

\section{Immunohistochemistry and light microscopy:}

Animals were slaughtered, Kidney and muscle samples from calf muscle were taken for histological evaluation. Kidney and muscle slices were fixed in $10 \%$ neutral buffered formalin for 24 h. After automated dehydration through agraded alcohol series, the slices were embedded in paraffin, sectioned at $5 \mu \mathrm{m}$. Then, sections were stained with hematoxylin and eosin, before being evaluated using light microscope. For immunohistochemistry, paraffin sections were mounted on aminopropyltriethoxysilaine (APES)-coated slides. To eliminate the endogenous peroxidase activity the sections were incubated in $0.3 \% \mathrm{H}_{2} \mathrm{O}_{2}$ for $30 \mathrm{~min}$. Antigen retrieval (unmasking) was done by heating slides in sodium citrate buffer $(\mathrm{pH}$ 6.0) at $95^{\circ} \mathrm{C}$ in a microwave for $15 \mathrm{~min}$ and slowly cooling them to room temperature. ${ }^{24}$ Sections were then incubated for $24 \mathrm{~h}$ at $4^{\circ} \mathrm{C}$ with the primary antibody; Nitric Oxide Synthase, endothelial (eNOS), Rabbit Polyclonal Antibody (Thermo Scientific, South San Francisco, California, USA; dilution 1:100). Immunohistochemical reaction was done using the standardized commercially available UltraVision Detection System anti-polyvalent HRP/DAB kit (Thermo Fisher scientific, USA). The slides were washed and incubated with biotinylated goat anti-polyvalent (goat anti-rabbit secondary antibody, dilution 1:200) for $10 \mathrm{~min}$ at room temperature. Then sections were incubated with streptavidin peroxidase for $10 \mathrm{~min}$ and finally with $0.05 \%$ diaminobenzidine (DAB) plus chromogen for 15 min. eNOS-positive cells appeared brown. Slides were examined using an Olympus CX41 optical microscope equipped with an Olympus EVOLT E-330 digital camera interfaced to a computer. Expression of eNOS protein was quantified for their relative densities using analysis densitometry tool from Image $\mathrm{J}$, Version $1.31 \mathrm{c}$ (National Institutes of Health, Bethesda, Maryland, USA). ${ }^{25}$

\section{Transmission electron microscopy}

Muscle specimens were fixed in $5 \%$ cacodylated-buffered glutaraldehyde for $24 \mathrm{~h}$ 
and postfixed in $1 \%$ osmium tetraoxide for 1 h. ${ }^{26}$ About $2 \mathrm{~mm}$-thick slices were processed and embedded in Epon-araldite mixture. Semithin sections of $1 \mu \mathrm{m}$ thickness were cut with a glass knife in KLB, Bromma Ultramicrotome, and stained with toluidine blue and examined. Ultrathin sections (450500 A) from muscle selected areas were cut with ultramicrotome, mounted on copper grids, stained with uranyl acetate and lead citrate, examined with a transmission electron microscope model JEM100CXII (JEOL, Tokyo, Japan), and photographed in the Assiut University Electron Microscopy Unit.

\section{Statistical analysis}

GraphPad Prism 5 (GraphPad Software Inc., La Jolla, CA, USA) was used for data analysis. Data were presented as mean +/SEM. Data compared among two groups using Paired Student's t Test. Data were compared among groups using One-Way Analysis of Variance (ANOVA) followed by Bonferroni Multiple comparison posthoc test. A $(P)$ value of less than 0.05 was considered to represent a statistically significant difference.

\section{RESULTS}

Effect of swimming versus swimming and vitamin $E$ on the plasma level of inflammatory cytokines in rats:

One bout of swimming exercise stress until exhaustion for seven consecutive days significantly raised INF-gamma $(\mathrm{p}<0.005)$ (Fig.
1A), TNF-alpha ( $<<0.005)$ (Fig. 1B), and CRP $(P$ $<0.01$ ) (Fig. 1C). Administration of Vitamin E (50 $\mathrm{mg} / \mathrm{kg}$, alpha tocopherol) prior to swimming bouts for seven consecutive days significantly decreased INF-gamma plasma level $(P<0.05)$ (Fig. 1A) and TNF-alpha plasma level $(P<0.01)$ (Fig. 1B) compared to $\mathrm{S}$ group. However vitamin $\mathrm{E}$ failed to decrease CRP plasma level. A significant rise in INF-gamma $(P<0.01)$ (Fig. 1A) and in TNFalpha $(P<0.005)($ Fig. 1B) in SE group versus $C$ group was found. An insignificant difference in CRP in SE group versus $\mathrm{C}$ group was found $(P>$ 0.05) (Fig. 1C).

Effect of swimming versus swimming and vitamin $E$ on plasma urea, plasma creatinine levels and BUN to creatinine ratio in rats:

One bout of swimming exercise stress until exhaustion for seven consecutive days caused significant decrease in plasma urea $(P<0.05)$ (Fig. 2A), decrease in plasma creatinine level $(P<$ 0.005) (Fig.2B), and increase in BUN to creatinine ratio $(P<0.01)$ in $\mathrm{S}$ group after half an hour of last swimming session compared to $\mathrm{C}$ group (Fig. 2C). Administration of Vitamin E $(50 \mathrm{mg} / \mathrm{kg}$, alpha tocopherol) for seven consecutive days prior to swimming sessions caused; insignificant change of plasma urea level in SE group compared to both C and $\mathrm{S}$ groups, insignificant change of blood creatinine level in $\mathrm{SE}$ group compared to $\mathrm{C}$ group was found, significant decrease in plasma creatinine level in $\mathrm{S}$ compared to SE groups $(P<$ 0.01). Vitamin E treatment significantly decreases BUN to creatinine ratio in SE group compared to $\mathrm{S}$ group $(P<0.05)$ (Fig. 2 C). Insignificant change in BUN to creatinine ratio in $\mathrm{C}$ group compared to SE group was found. (Fig. 2C). 
A

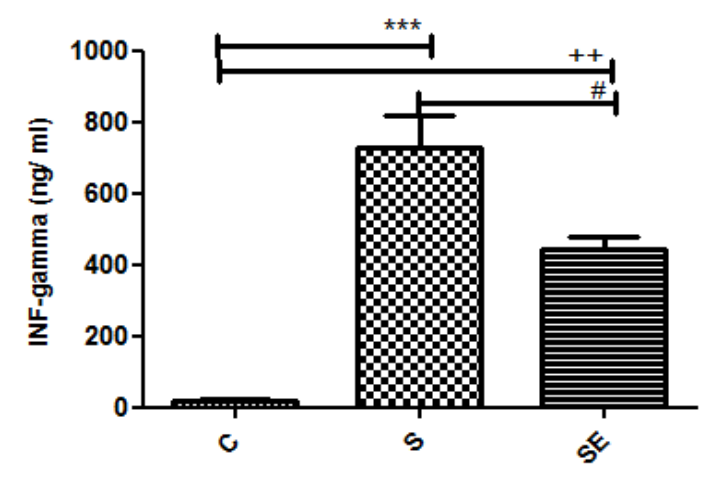

B

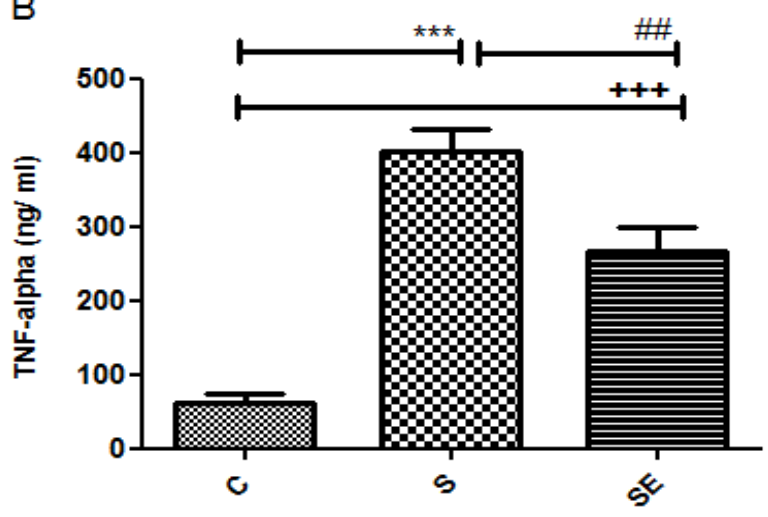

$\mathrm{C}$

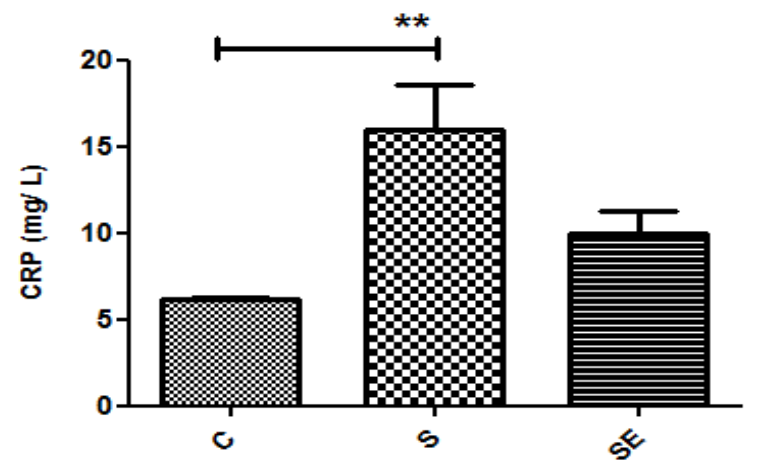

Fig. (1): Effect of swimming versus swimming and vitamin E on plasma level of INF-gamma (A), tumor necrosis factor alpha (TNF- $\alpha$ ) (B), C-reactive protein (CRP ) (C) in rats: C: control, S: swimming, SE: swimming and vitamin E. All values are expressed as mean +/-SEM, One Way ANOVA with Bonferroni's Multiple Comparison Test. $(*)$ significance of $\mathrm{S}$ vs $\mathrm{C}$ group, (+) significance of $\mathrm{SE}$ vs $\mathrm{C}$ group, (\#) significance of $\mathrm{S}$ vs $\mathrm{SE}$ group $(p<0.05$ is considered as significant,

A

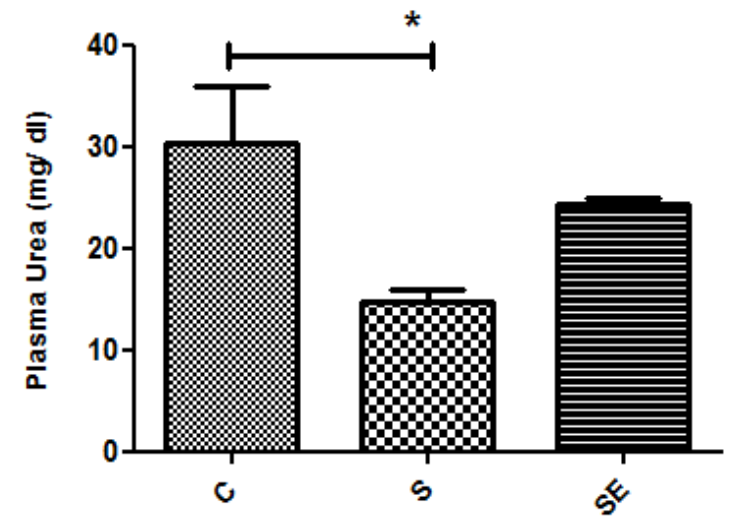

Figure (2) Effect of swimming versus swimming and vitamin $\mathrm{E}$ on plasma urea, creatinine, and BUN: creatinine ratio in rats: C: control, S: swimming, SE: swimming and vitamin E. All values are expressed as mean +/-SEM, One Way ANOVA with Bonferroni's Multiple Comparison Test. (*) significance of S vs C group, (+) significance of $\mathrm{S}$ vs $\mathrm{SE}$ group $(p<0.05$ is considered as significant, $\mathrm{n}=8$ ).
B

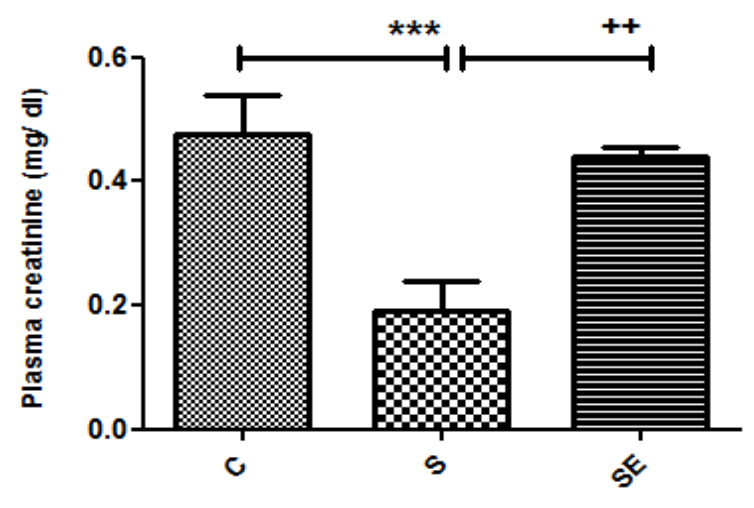

C

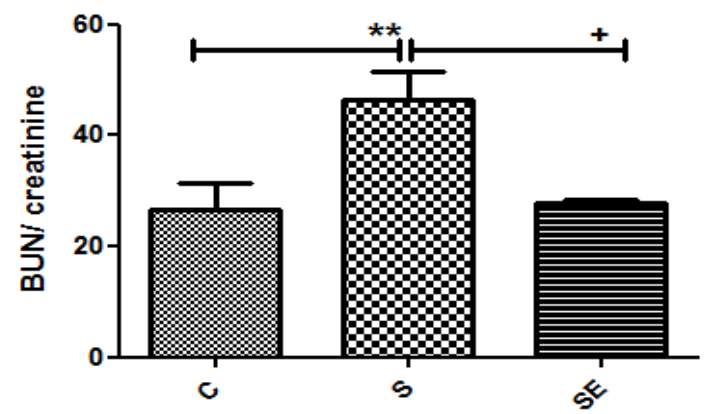


A

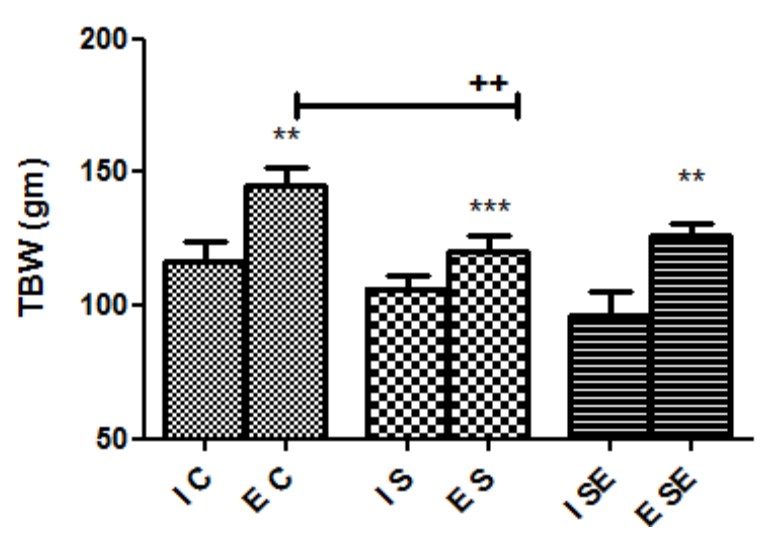

C

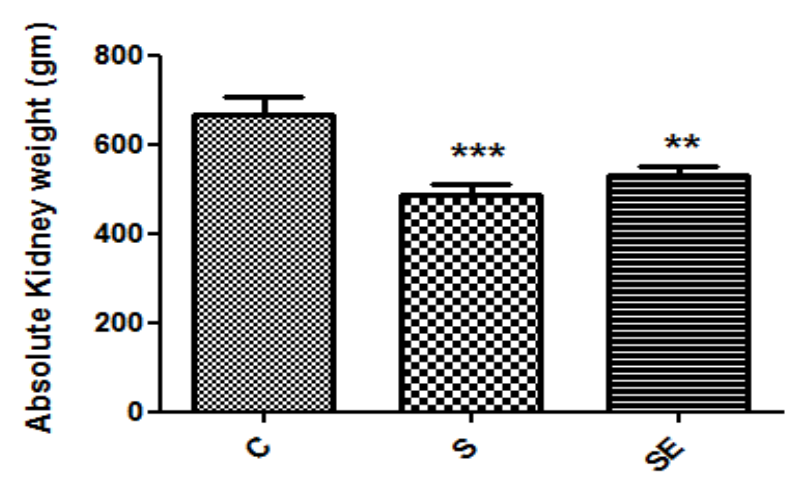

B
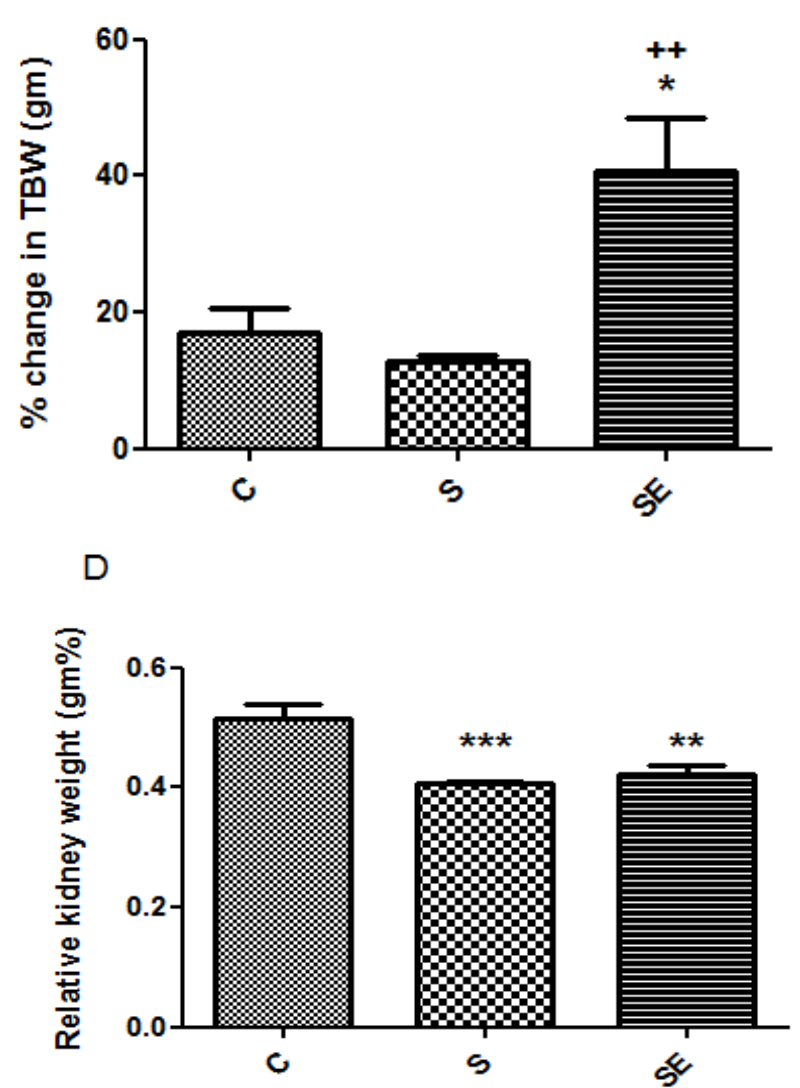

Fig. (3) Effect of swimming versus swimming and vitamin E on total body weight (TBW) (A), \% change in TBW (B), Absolute kidney weight (C), and relative kidney weight (D) of rats, C: control, S: swimming, SE: swimming + vitamin E, IC: initial weight of control, EC: end weight of control, , IS: initial weight of S group, ES: end weight of S group, , ISE: initial weight of SE group, ESE: end weight of SE group. All values are expressed as mean +/-SEM, Paired t test was used for comparing initial and final TBW in (A). One way ANOVA with Bonferroni's Multiple Comparison Test was used for comparison among groups. In A; $(*)$ significance of end TBD vs initial TBW for each group, $(+)$ significance of ES vs EC; In B, C, \& D (*) significance of S or SE group vs C group, $(+)$ significance of SE vs $\mathrm{S}$ group, $(p<0.05$ is considered as significant, $\mathrm{n}=8$ ).

Effect of swimming versus swimming and vitamin $E$ on total body weight (TBW) and kidney weight:

One bout of swimming exercise stress until exhaustion for seven consecutive days significantly decreased TBW in S group compared to control group (Fig. 3A). Administration of vitamin $\mathrm{E}$ caused significant rise in \% change in TBW compared to both control and swimming groups (Fig. 3B). Insiginificant difference in initial weight between the three groups and significant rise in TBW for all groups compared to their initial weight was found (Fig. 3A). Swimming exercise stress significantly decreased absolute as well as relative kidney weight in both $\mathrm{S}$ and $\mathrm{SE}$ groups compared to $\mathrm{C}$ group (Fig. 3C \& 3D).

\section{Effect of swimming versus swimming and} vitamin E on kidney structure:

Changes of kidney sections stained by HE: C group (Fig. 4A) showed normal glomerular shape, capillary size, and normal renal tubules epithelium. In contrast, the rats in $\mathrm{S}$ group showed glomerular congestion and swelling, disintegration of tubular 
epithelium, dilated tubular lumen (Fig. 4B). Such pathological changes were slighter in the rats of
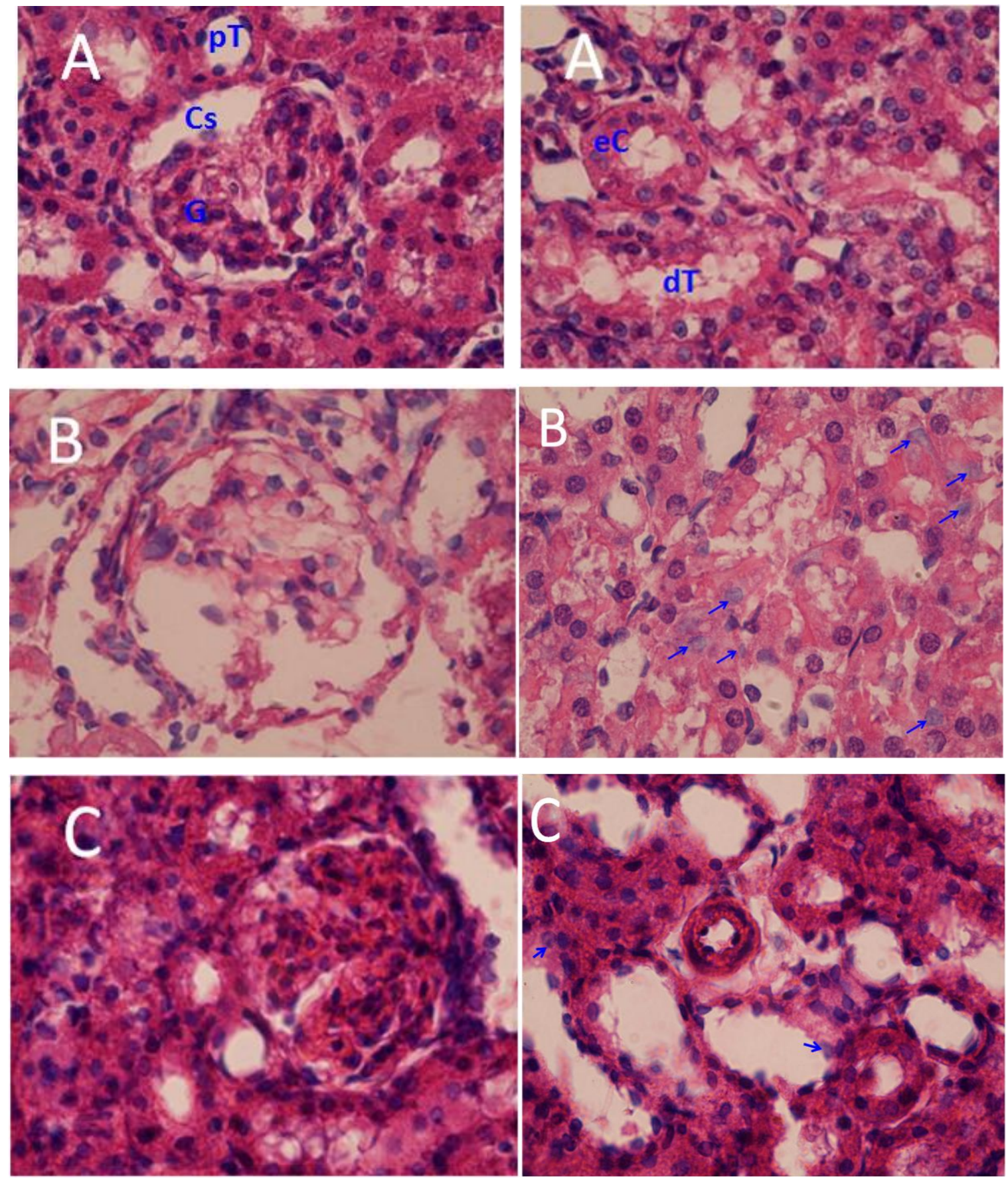

Fig. (4): Photomicrographs of renal tissue stained by HE. Left panel: glomeruli, right panel: tubules; A: rat from control group; B: rat from swimming group; $\mathrm{C}$, rat from swimming plus vitamin $\mathrm{E}$ group. Tubule epithelium (eC), proximal convoluted tubules (pT), distal convoluted tubules (dT), glomerulus (G), capsular space (Cs); faintly stained nuclei (arrows) in B \& C. ( $\times 400$, the same indications for the all figures). 
Effect of swimming versus swimming and vitamin E on skeletal muscle structure:

\section{Changes of gastrocnemeus muscle stained by} $\mathrm{HE}$ :

LS of control (C) skeletal muscle showing elongated unbranched muscle fibers with an acidophilic cytoplasm, eccentric located nuclei and a striated appearance. There are a few connective tissue nuclei between the fibers (Fig. 5 upper left panel). LS of swimming (S) skeletal muscle showing elongated fibers, with splitting of some fibers, areas of degenerated fibers, increased nuclear number, and centrally located nuclei (arrows) can also be seen in some fibers (Fig. 5 middle left panel). There are some connective tissue nuclei between the fibers. LS of swimming and vitamin E (SE) skeletal muscle showing elongated unbranched fibers, fewer normally located nuclei with an acidophilic cytoplasm and a striated appearance. There are some connective tissue nuclei between the fibers (Fig. 5 lower left panel). CS of control (C) skeletal muscle shows normal appearance; CS of swimming (S) skeletal muscle showing swollen edematous fibers with increased markedly expanded blood vessels, focal interstitial cellular infiltration and many centrally located nuclei; CS of swimming and vitamin E (SE) showing nearly normal appearance (Fig. 5 right panel).

Changes of gastrocnemeus muscle with transmission electron micrograph (TEM): Control group (Fig 6.1) showing normal ultrastructure of skeletal muscle. Swimming group (Fig 6. 2, 6.4, \& 6.6) showing areas of degeneration and loss of myofilaments, lower number of vesicles at the storage sites and rise at the active sites, increased number and size of sarcoplasmic reticulum cisterae, increased number and marked dilation of blood capillaries, upregulation of mitochondria, increased number of satellite cells, wavy z discs, abnormal centrally located nuclei. Vitamin $\mathrm{E}$ and swimming group (Fig 6.3, 6.5, \& 6.7) showing marked decrease in the number of vesicles at storage pool and recruitment to release sites, marked increase in number of mitochondria, size of sarcoplasmic reticulum sacs compared to $\mathrm{S}$ group, areas of apparent loss of muscle fibers, increased number of myonuclei, areas of collagen deposition, and well aliened contractile machinery

Effect of swimming versus swimming and vitamin $E$ on eNOS expression in gastrocnemeus muscle by immunohistochemistry

Swimming causes significant rise in eNOS expression compared to control. Prophylactic use of vitamin $\mathrm{E}$ before exercise significantly elevated eNOS expression in skeletal muscle compared to both control and swimming group (Fig. 7a \& 7b)

\section{Discussion:}

Inflammation is a protective process that is important for repair of damaged tissues and fighting foreign bodies. ${ }^{27}$ Exercise represents a physical stress that affects homeostasis. ${ }^{28}$ Mild exercise as a stressor has the ability to modulate function of the immune system. ${ }^{29}$ The body deals with physical activity as any pathological condition that causes acute subclinical inflammatory state. ${ }^{30}$ We found that a bout of swimming exercise for one hour/day repeated 

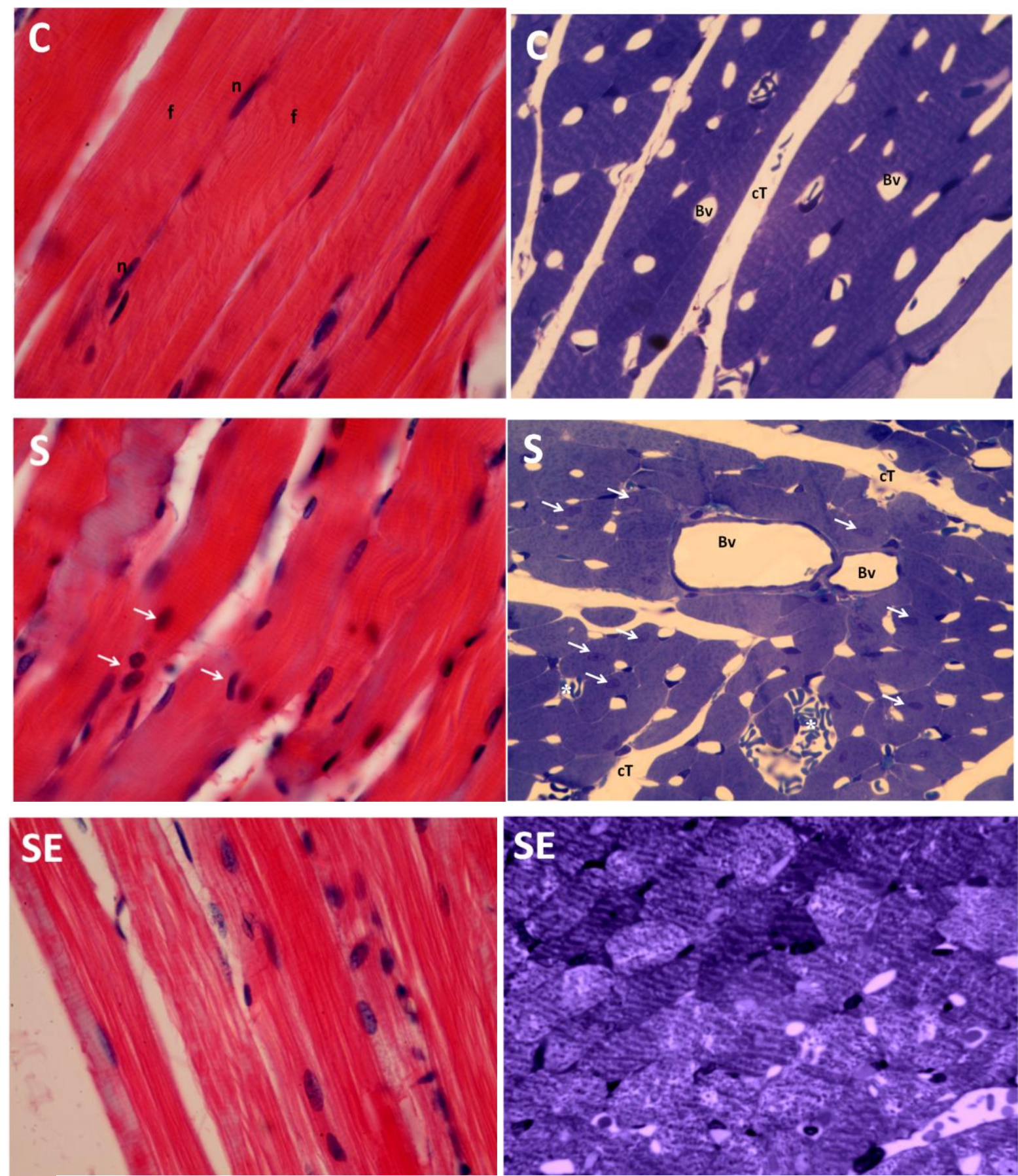

Fig. (5): Photomicrographs of gastrocnemeus muscle stained by HE. LS: Longitudinal section (left panel); CS: Cross section (right panel); C, rat from control group ; S, rat from swimming group ; SE, rat from swimming and vitamin E group. Muscle fibers (f), normally located nuclei (n), centrally located nuclei (arrows), blood vessels (Bv), connective tissue (cT), focal interstitial cellular infiltration $(*) .(\times 400$, the same indications for all following figures $)$.

daily for a week caused significant rise of proinflammatory cytokines; TNF- $\alpha$, IFN $\gamma$, and CRP. Our results are supported by previous studies reporting that circulating basal levels of TNF- $\alpha$ were raised by acute extenuating exercise. ${ }^{1}$ Significant activation of TNF- $\alpha$ and other cytokines is also reported after unaccustomed muscle contractions that cause microdamage to sarcomeres. ${ }^{31,32}$ Other studies demonstrated that 
TNF- $\alpha$ and IFN $\gamma$ through activation of NF- $k$ B caused proliferation and at the same time inhibition of differentiation of myoblasts. ${ }^{33,} 34$ It was reported that TNF- $\alpha$ caused elevation of IL- 6 , CRP and haptoglobin through inducing their synthesis. ${ }^{35}$ The rise in CRP level after swimming exercise is supported by another study that reported a maintained rise in CRP and leukocyte count starting after 30 min of marathon swimming and continued for 8 days after recovery. ${ }^{36}$

\section{A}
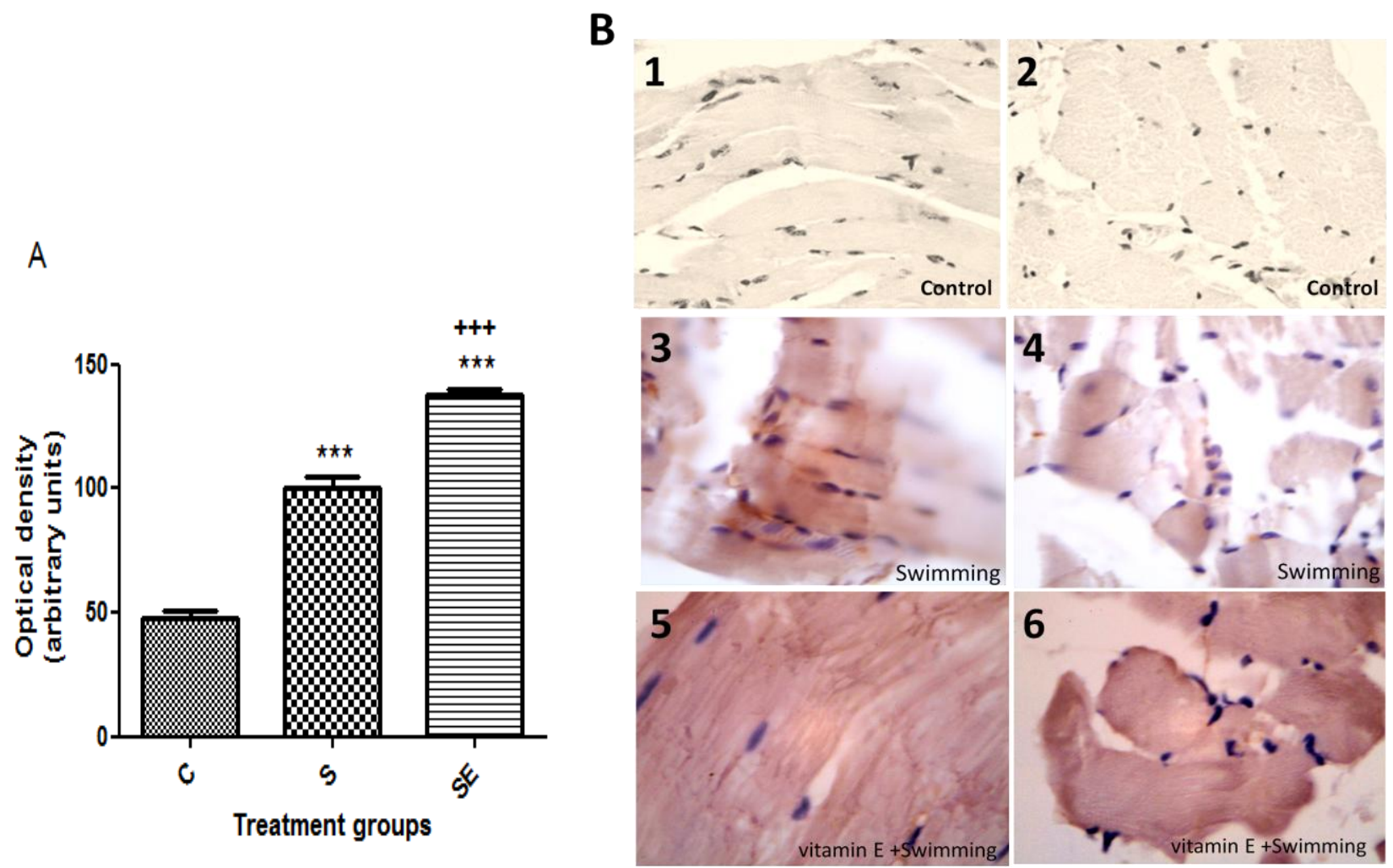

Fig. (7) Effect of swimming versus swimming and vitamin E on endothelial nitric oxide synthase (eNOS) expression in rat skeletal muscle. A: Mean density of eNOS in S and SE groups analyzed by image J software. B. Left panel (LS sec.) and right panel (CS sec) photomicrographs of rat gastrocnemeus muscle showed immunohisto-chemistry expression of eNOS. B1 \& 2 from C group, B3 \& B4 from S group, B5 \& 6 from SE group, C: control, S: swimming, SE: swimming + vitamin E, (*) significance of $\mathrm{S}$ or SE group vs C group, (+) significance of SE vs $\mathrm{S}$ group, $(p<0.05$ is considered as significant, $\mathrm{n}=7$ ).

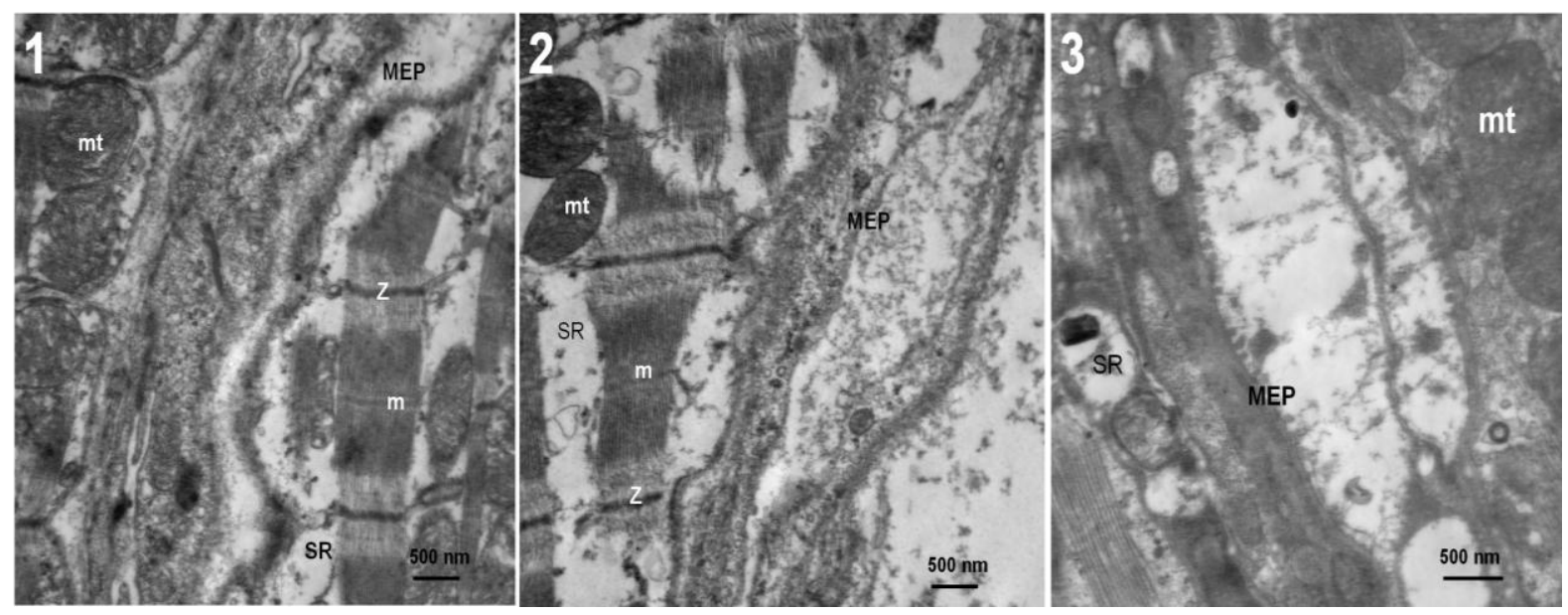




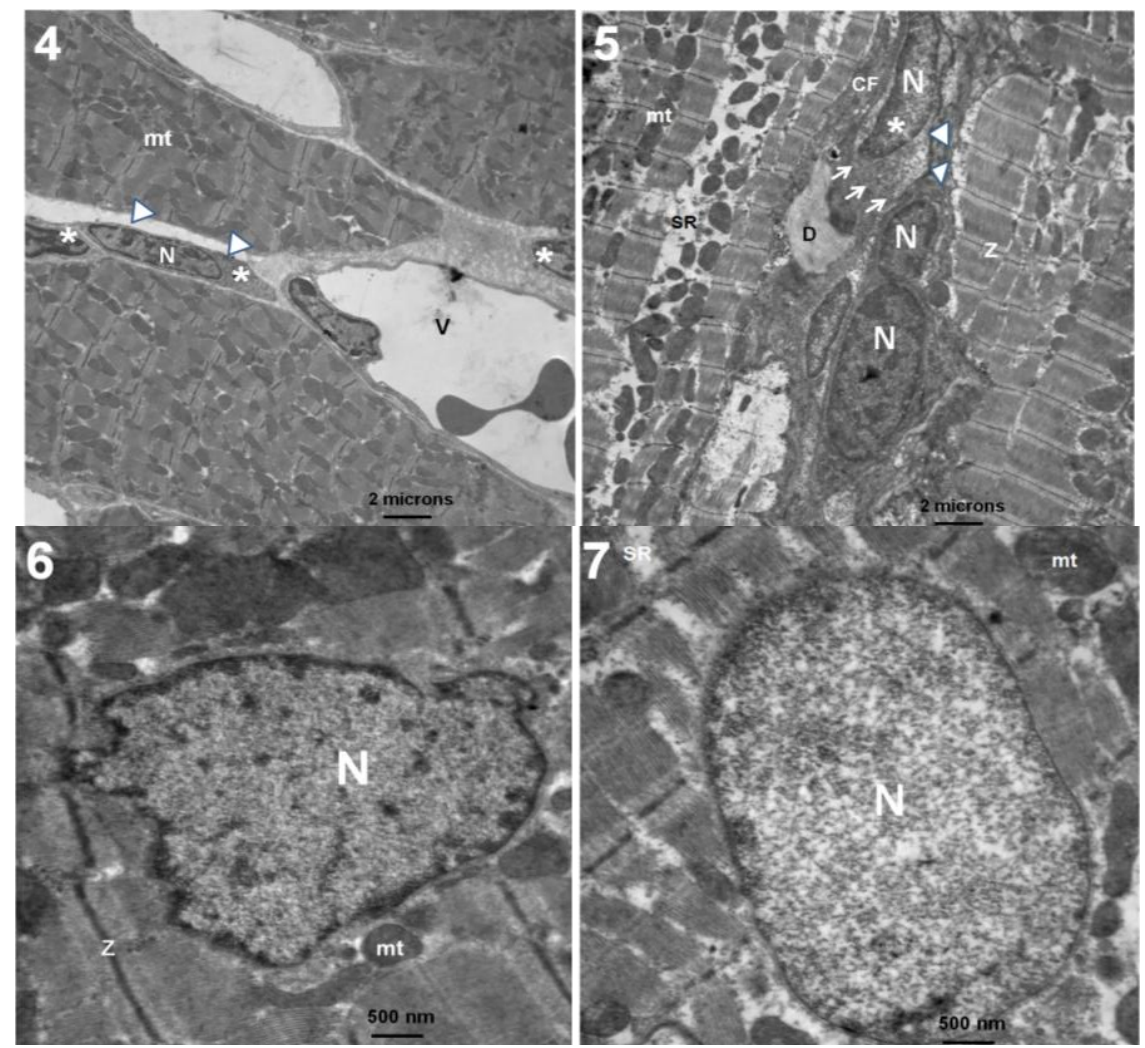

Fig. (6): Transmission electron micrograph of a portion of rat gastrocnemeus muscle with different magnification from; $\mathrm{C}$ group (1), S group (2, 4, 6), SE group (3, 5, 7); (mt) mitochondria, (Z) Z discs, (m) m line, (MEP) motor end plates, acetylcholine vesicles (Ach V), areas of lysosomal glycogen deposition at the cell periphery (D), myonuclei (N), nucleus of satellite cell $(*)$,cell membrane of satellite cells (arrow heads) collagen fibers (CF), \& sacs of sacoplasmic reticulum (SR). Magnification 7.1 (X 14,000); 7.2 (X 14000) 7.3 (X 19000), 7.4 \&7.5 (X 3600), 7.6 \& 7.7 ( 14000).

Our results also revealed that vitamin $\mathrm{E}$ administration just before the exercise greatly improved muscle structure and significantly decreased circulating levels of TNF- $\alpha$ and INF- $\gamma$. The beneficial effect of vitamin $\mathrm{E}$ on muscle structure is supported by previous studies. Those studies proved the role of antioxidant in skeletal muscle cell including the control of gene expression, regulation of cell signaling pathways, and modulation of muscle force production. ${ }^{37,38,10}$ The ability of vitamin E to lower INF- $\gamma$ and TNF- $\alpha$ levels is supported by the work of Belisle and his colleagues who observed a strong relationship between vitamin $\mathrm{E}$ supplementation and IFN- $\gamma$ as well as TNF- $\alpha$ that is dependent on individual's immune response at the onset of supplementation. ${ }^{15}$ Studies done in Finland and Italy demonstrated that $\alpha$-tocopherol form of vitamin E exert anti-inflammatory actions and is effective in reducing asthma. ${ }^{39}$ An in vitro study showed that pretreatment of endothelial cells overnight with D- $\alpha$-tocopherol inhibited leukocyte migration. $^{40}$ We found also that vitamin $\mathrm{E}$ supplementation caused insignificant change in the level of CRP in SE group compared to $\mathrm{S}$ group. This result is supported by the work of Block and his group who reported that treatment with vitamin $C$ but not $\mathrm{E}$ caused significant decrease in circulating levels of CRP among healthy nonsmokers with CRP higher than $1.0 \mathrm{mg} / \mathrm{L} .{ }^{41} \mathrm{~A}$ fairly recent study revealed that $\mathrm{TNF}-\alpha$ increases the oxidative stress in fatty hepatocytes. ${ }^{5}$ Taken together, we may speculate that vitamin $\mathrm{E}$ have 
dual antioxidant action direct as well as indirect through its anti-inflammatory effect.

Although, this study showed that unaccustomed exercise stress repeated daily caused significant decrease in plasma urea and creatinine levels, it raised urea to creatinine ratio and significantly decreased relative kidney weight. The beneficial effect of exercise on blood urea and creatinine is supported by the work of Drygas and his colleagues who reported decrease in blood urea and creatinine after $30 \mathrm{~min}$ and a rise starting after 4 hours of marathon swimming in open water. ${ }^{36}$ Another study suggested that the lowering of blood urea and creatinine levels after $60 \mathrm{~min}$ of swimming exercise is due to inhibition of myofibroblast transdifferentiation in chronic renal disease. ${ }^{42}$ The dangerous effect of raised urea to creatinine ratio is supported by two recent studies reporting that it helps to detect a high-risk form of renal impairment in patient with decompensated heart failure. ${ }^{43}$ and in patients with Cholera. ${ }^{44}$ Since rise of urea to creatinine ratio is predictive of prerenal injury, we suggest that swimming exercise stress causes dehydration. This dehydration state enhanced renal tubular reabsorption of urea that follows the enhanced transport of sodium and water in proximal tubules and decreased free water clearance in collecting tubules causing disproportionate rise of urea to creatinine ratio. ${ }^{45}$

Our results demonstrated that vitamin E significantly reduces blood urea to creatinine ratio in SE group compared to $\mathrm{S}$ group suggesting that vitamin $\mathrm{E}$ is protective against dehydration and expected renal damage associated with exhaustive exercise stress. Moreover, vitamin E supplementation significantly raised \% change in TBW compared to both $\mathrm{C}$ and $\mathrm{S}$ groups. This result is supported by a study done by Azman and his group reporting that vitamin E played an important role in the weight gain and excessive vitamin $\mathrm{E}$ intake might cause obesity through increasing fat mass in female rats. ${ }^{20}$ Another study reporting lower death rate and higher body weight among lambs whose mother ewes were fed additional vitamin $\mathrm{E}$ for 3 weeks before lambing. ${ }^{46}$ In addition, this study showed that vitamin $\mathrm{E}$ markedly improved the acute exercise induced damage of kidney structure. In agreement with our result, two studies showed that deficiency of vitamin $\mathrm{E}$ in diet led to renal injury in healthy kidney of rats ${ }^{17}$ and worsened renal structural as well as functional damage following ischemia reperfusion injury. ${ }^{47}$

This study also revealed that acute unaccustomed exercise caused changes of skeletal muscle structure characterized by increased vascularity, splitting of muscle fibers, abnormality of structural alignment of the sarcomeres, abnormal nuclear shape, location, apparent rise of nuclear number, and increased size and number of mitochondria. In line with us many previous studies revealed that exercise increased both number ${ }^{48}$, size ${ }^{49}$, and volume density of mitochondria. ${ }^{50}$ Other studies reported an increase of capillary density, capillaryto-fiber ratio with moderate swimming exercise ${ }^{51}$, and disorganization of myofilaments induced by swimming at temperatures $\left(28\right.$ and $\left.42^{\circ} \mathrm{C}\right) .^{52}$ Administration of vitamin $\mathrm{E}$ for seven consecutive days before the exposure to swimming returned the structural alignment of sarcomeres with 
apparent further increase in size of mitochondria, sarcoplasmic reticulum cisterae, number of satellite cells and enhanced recruitment of acetylcholine vesicles to release sites at motor end plates. In agreement with this result a previous study reported extensive skeletal muscle degeneration in the young animals caused by vitamin E deficiency. ${ }^{18}$ The ability of satellite cells to proliferate maintains stem cell and increased the number of myogenic cells that cause formation of new myofiber and regain a functional contractile apparatus has been reported. ${ }^{53}$ Taken together, we suggest that vitamin $\mathrm{E}$ supplementation before severe exercise through increasing number of satellite cells helps to maintain healthy functional contractile proteins.

In addition, results of the present work revealed an increased expression of eNOS in gastrocnemeus muscle with vitamin $\mathrm{E}$ supplementation prior to swimming sessions compared to swimming alone. In line with this result Ülker and his group reported an increased activity of eNOS and production of NO that is associated with decreased superoxide formation induced by high concentrations of vitamin $\mathrm{E}(100 \mathrm{~mol} / \mathrm{L})$ in rat aorta. ${ }^{19}$ Moreover, previous studies revealed that eNOS has protective effect through producing low amount of nitric oxide (NO) that participate in regulation of haemodynamic, vascular smooth muscle cells proliferation, and vasomotor tone. ${ }^{54}$ Therefore, we may speculate that vitamin $\mathrm{E}$ through increasing the expression of eNOS produce considerable amount of NO that regulate haemodynamics and proliferation of skeletal muscle.

\section{In conclusion:}

We suggested that supplementation of the alpha tocopherol form of vitamin $\mathrm{E}$ before acute unaccustomed swimming exercise might be beneficial prophylactic measure against elevated inflammatory markers, kidney and skeletal muscle damage.

\section{Acknowledgement:}

The Author would like to thank Dr. Manal M. Gomea Assistant professor department of Human Histology, and Dr Ayman S. Amer Lecturer department of human Anatomy and Embryology Department of Human Anatomy and Embryology Faculty of Medicine, Assiut University, Assiut, Egypt for their great help in preparing histology sections.

\section{References:}

1. Teixeira de Lemos E, Pinto R, Oliveira J, Garrido P, Sereno J, Mascarenhas-Melo $F$, Pascoa-Pinheiro J, Teixeira F, Reis F. Differential effects of acute (extenuating) and chronic (training) exercise on inflammation and oxidative stress status in an animal model of type 2 diabetes mellitus. Mediators of Inflammation. Vol 2011, ID 253061, 8 pages, 2011.

2. Borghouts LB, Keizer HA. Exercise and insulin sensitivity: a review. International J Sports Med. 21 (1), 1-12, 2000.

3. Pedersen BK. The diseasome of physical inactivity - and the role of myokines in muscle-fat cross talk. J Physiol. 587 (23), 5559-5568, 2009.

4. Plaisance EP, Grandjean PW. Physical activity and high sensitivity $\mathrm{C}$ - reactive protein. J Sports Med. 36(5), 443-458, 2006. 
5. Golbidi S, Laher I. Exercise Induced Adipokine Changes and the Metabolic Syndrome. Journal of Diabetes Research. Vol. 2014, ID 726861, 16 pages, 2014.

\section{Schroder K, Hertzog PJ, Ravasi T, Hume} DA. Interferon-gamma: an overview of signals, mechanisms and functions. J Leukoc Biol. 75(2), 163- 89, 2004.

7. Thompson D, Pepys MB, Wood SP. The physiological structure of human C-reactive protein and its complex with phosphocholine. Structure. 7 (2), 169-77, 1999.

\section{Reid MB, Haack KE, Franchek KM, Valberg} PA, Kobzik L, West MS. Reactive oxygen in skeletal muscle. I. Intracellular oxidant kinetics and fatigue in vitro. J Appl Physiol. 73:17971804, 1992.

\section{Reid MB, Andrade FH, Balke CW, Esser}

KA. Redox mechanisms of muscle dysfunction in inflammatory disease. Phys Med Rehabil Clin N Am, 16:925-949, 2005.

10. Reid MB. Nitric oxide, reactive oxygen species, and skeletal muscle contraction. Med Sci Sports Exerc. 33(3),371-6, 2001.

11. Smith MA, Reid MB. Redox modulation of contractile function in respiratory and limb skeletal muscle. Respir Physiol Neurobiol. 151:229-241, 2006.

12. Powers SK, Ji LL, Kavazis AN, and Jackson MJ. Reactive oxygen species: impact on skeletal muscle. Compr Physiol. 1(2), 941-969, 2011.

13. Morgan D B, Carver ME, Payne RB. Plasma creatinine and urea: creatinine ratio in patients with raised plasma urea. Br Med J. 2, 929-932, 1977.
14. Kerr DNS, Davison JM. The assessment of renal function. BRIT J HOSP MED 14, 360-372, 1975.

15. Belisle SE, Leka LS, Dallal GE, Jacques PF, Delgado-Lista J, Ordovas JM, Meydani SN. Cytokine response to vitamin E supplementation is dependent on pre-supplementation cytokine levels. Biofactors. 33(3), 191- 200, 2008.

16. Cook-Mills JM, McCary CA. Isoforms of vitamin $\mathrm{E}$ differentially regulate inflammation. Endocr Metab Immune Disord Drug Targets. 10 (4), 348-66, 2010.

17. Nath KA, Salahudeen AK. Induction of renal growth and injury in the intact rat kidney by dietary deficiency of antioxidants. J Clin Invest. 86 (4), 1179-92, 1990.

18. Van Vleet JF, Hall BV, Simon J . Vitamin E deficiency: a sequential study by means of light and electron microscopy of the alterations occurring in regeneration of skeletal muscle of affected weanling rabbits. Am J Pathol. 51(5): 815-830m 1967.

19. Ülker S, McKeown PP, Bayraktutan U. Vitamins reverse endothelial dysfunction through regulation of eNOS and $\mathrm{NAD}(\mathrm{P}) \mathrm{H}$ oxidase activities. Hypertension, 41:534-539, 2003.

20. Azman A, Khalid BAK, \& Ima-Nirwana S. The effects of vitamin $\mathrm{E}$ on bodyweight and fat mass in intact and ovariectomized female rats. Medical Journal of IAS. 14 (4), 125-138, 2001.

21. Zhang, C, Lu Y, Guo GX, Zhang H. Studies on Antifatigue of Buckwheat Protein. J. Wuxi Univ. Light Ind. 24, 78-82, 2005.

22. Radák Z, Kaneko T, Tahara S, Nakamoto H, Ohno H, Sasvári M, Nyakas C, Goto S. The effect of exercise training on oxidative damage of lipids, proteins, and DNA in rat skeletal muscle: 
evidence for beneficial outcomes. Free Radic Biol Med. 27, 69-74, 1999.

23. Hosten AO. BUN and Creatinine. In: Walker HK, Hall WD, Hurst JW, editors. Clinical Methods: The History, Physical, and Laboratory Examinations. 3rd edition. Boston: Butterworths; 1990. Chapter 193.

24. Cattoretti G, Pileri S, Parravicini C, Becker MHG, Poggi S, Bifulco $\mathbf{C}$, et al. Antigen unmasking on formalin-fixed, paraffin-embedded tissue sections, J Pathol. 171, 83-98, 1993.

25. Sage D, Unser M. Easy Java Programming for Teaching Image Processing. From: www.bigwww.epfl.ch/publications/sage 0101. html Accessed Jan 2014.

26. Bozzola JJ, Russell LD. Electron microscopy: principles and techniques for biologists. 2nd Sub ed. Boston: Jones \& Bartlett Pub. ISBN-13: 9780763701925, 1992.

27. Radak Z, Zhao Z, Koltai E, Ohno H, Atalay M. Oxygen Consumption and Usage During Physical Exercise: The balance between oxidative stress and ROS-dependent adaptive signaling. Antioxid Redox Signal. 18(10), 1208-46, 2013.

28. Mastorakos G, Pavlatou M. Exercise as a stress model and the interplay between the hypothalamus-pituitaryadrenal and the hypothalamuspituitary-thyroid axes. Horm Metab Res. 37(9), 577-584, 2005.

29. Schulz KH, Gold SM, Witte J, Bartsch K, Lang UE, Hellweg R, Reer R, Braumann KM, Heesen C. Impact of aerobic training on immuneendocrine parameters, neurotrophic factors, quality of life and coordinative function in multiple sclerosis. J of the Neurol Sci. 225(1-2), 11-18, 2004.
30. Martin-Cordero L, Garcia JJ, Hinchado MD, Bote E, Manso R, Ortega E. Habitual physical exercise improves macrophage IL-6 and TNF-03b1 deregulated release in the obese zucker rat model of the metabolic syndrome. Eur J Appl Physiol 107, 535-543, 2009.

31. Budford TW, Cooke MB, Shelmadine BD, Hudson GM, Redd L, Willoughby DS. Effects of eccentric treadmill exercise on inflammatory gene expression in human skeletal muscle. Appl Physiol Nutr Metab. 34, 745-53, 2009.

32. Liao P, Zhou J, Ji LL, \& Zhang Y. Eccentric contraction induces inflammatory responses in rat skeletal muscle: role of tumor necrosis factoralpha. Am J Physiol Regul Integr Comp Physiol. 298 (3), R599-R607, 2010.

33. Foulstone EJ, Meadows KA, Holly JM, Stewart CE. Insulin-like growth factors (IGF-I and IGF-II) inhibit $\mathrm{C} 2$ skeletal myoblast differentiation and enhance TNF alpha-induced apoptosis. J Cell Physiol. 189 (2), 207-15, 2001.

34. Guttridge DC, Mayo MW, Madrid LV, Wang CY, Baldwin AS. NF-kappaB-induced loss of MyoD messenger RNA: possible role in muscle decay and cachexia. Science. 289(5488), 2363-66, 2000.

35. Petersen AM, Pedersen BK. The antiinflammatory effect of exercise, J Appl Physiol. 98(4), 1154-1162, 2005.

36. Drygas W, Rębowska E, Stępień E, Golański J, Kwaśniewska M. Biochemical and hematological changes following the $120-\mathrm{Km}$ open-water marathon swim. JSSM. 13, 632-637, 2014.

37. Powers SK, Duarte J, Kavazis AN, Talbert EE. Reactive oxygen species are signaling 
molecules for skeletal muscle adaptation. expphysiol. 95(1-9), 2010.

38. Droge W. Free radicals in the physiological control of cell function. physrev. 82(1), 47-95, 2002.

39. Tabak C, Smit HA, Rasanen L, Fidanza F, Menotti A, Nissinen A, Feskens EJ, Heederik D, Kromhout D. Dietary factors and pulmonary function: a cross sectional study in middle aged men from three European countries. Thorax, 54(11), 1021-1026, 1999.

40. Berdnikovs S, Abdala-Valencia H, McCary C, Somand M, Cole R, Garcia A, Bryce P, Cook-Mills J. Isoforms of vitamin E have opposing immunoregulatory functions during inflammation by regulating leukocyte recruitment. J Immunol. 185 (2), 1341, 2009.

41. Block G, Jensen C, Dalvi V, Norkus E, Hudes M, Crawford P, Holland N, Fung E, Schumacher L, Harmatz $\mathbf{P}$. Vitamin $\mathrm{C}$ treatment reduces elevated C-reactive protein. Free Radic Biol Med. 46 (1), 70-7, 2009.

42. Peng CC, Chen KC, Hsieh CL, Peng RY. Swimming exercise prevents fibrogenesis in chronic kidney disease by inhibiting the myofibroblast transdifferentiation. PLoS One. 7(6), e37388, 2012.

43. Brisco MA, Steven G, Coca, DO, Chen J, Owens AT, Brian D. McCauley BS, Kimmel SE, and Testani JM. Blood urea nitrogen/creatinine ratio identifies a high-risk but potentially reversible form of renal dysfunction in patients with decompensated heart failure. Circ Heart Fail. 6(2), 233-239, 2013.

44. Tariq M, Memon M, Jafferani A, Shoukat S, Gowani SA, et al. Massive Fluid Requirements and an Unusual BUN/Creatinine Ratio for Pre-
Renal Failure in Patients with Cholera. PLoS ONE. 4(10), e7552, 2009.

45. Walker HK, Hall WD, \& Hurst JW. Clinical methods: the history, physical, and laboratory examinations. In BUN and creatinine Text book, 3rd ed. Hosten AO. Chapter 193. Boston: Butterworths, ISBN-10: 0-409-90077-X, 1990.

46. Kott RW, Thomas VM, Hatfield PG, Evans T, Davis KC. Effects of dietary vitamin E supplementation during late pregnancy on lamb mortality and ewe productivity. J Am Vet Med Assoc. 212(7), 997-1000, 1998.

47. Nath KA, Paller MS. Dietary deficiency of antioxidants exacerbates ischemic injury in the rat kidney. Kidney Int. 38(6), 1109-17, 1990.

48. Gollnick PD, King DW. The immediate and chronic effect of exercise on the number and structure of skeletal muscle mitochondria. Biochem. Exerc. Med. Sport 3:239-244, 1969.

49. Kiessling KH, Piehl K, Lundquist CG. Effect of physical training on ultrastructural features in human skeletal muscle. In: Muscle Metabolism during Exercise, Pernow B. and Saltin B. (Eds.). New York: Plenum Press, pp. 97-101, 1971.

50. Howald H, Hoppeler H, Claassen H, Mathieu O, Straub R. Influences of endurance training on the ultrastructural composition of the different muscle fiber types in humans. Pflugers Arch. 403:369-376, 1985.

\section{Medeiro A, Vanzelli AS, Rosa KT, Irigoyen} MC, Brum PC. Effect of exercise training and carvedilol treatment on cardiac function and structure in mice with sympathetic hyperactivityinduced heart failure. Braz J Med Biol Res, 41(9): 812-817, 2008. 
52. Wang KT. Structural changes in rat skeletal muscle induced by swimming at high temperatures (28 and $42^{\circ}$ C). Med Electron Microsc. 29(1), 2836, 1996.

53. Yin H, Price F, Rudnicki MA. Satellite cells and the muscle stem cell niche. Physrev. 93(1): 23-67, 2013.
54. Albrecht EW, Stegeman CA, Heeringa $P$, Henning, Goor H. Protective role of endothelial nitric oxide synthase. J Pathol. 199, 8-17, 2003. 


\section{فيتامين هاء يؤدى إلى التقليل من الضرر الناجم عن التمارين الرياضية الحادة في الكلى و العضلات الهيكلية

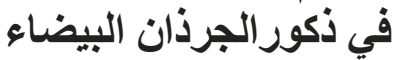 \\ غاده سعد زغلول أحمد محمود البرد}

قسم الفسيولوجيا الطبية ـ كلية الطب - جامعة أسيوط

الهوف. ممارسة الرياضة يعزز طول العمر ويؤدى إلى التقليل من المو اد المؤكسدة. ومع ذلك فان ممارسة الرياضة العنيفة أو المر هقة على المدى القصير يزيد من تشكيل أنو اع الأكسجين التفاعلية الضارة. وتستخدم مضادات الأكسدة على نطاق و اسع

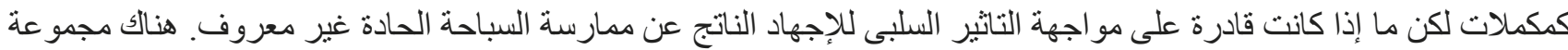

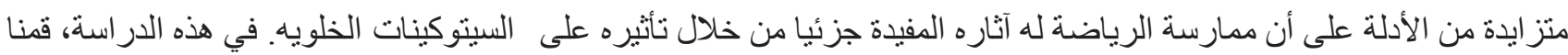

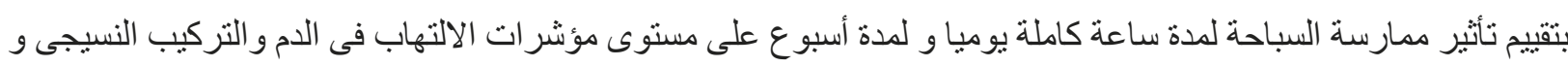

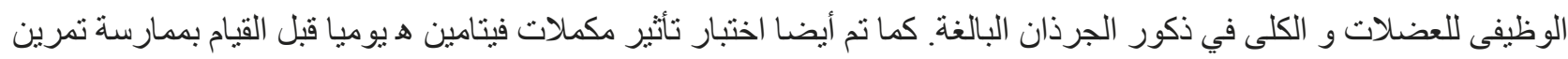

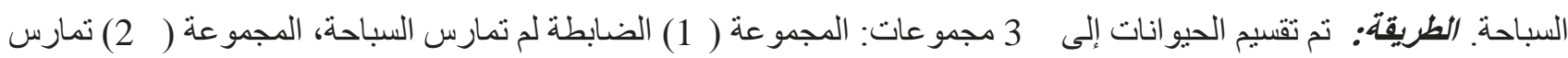
السباحة يو ميا لمدة ساعة على مدى سبعة أيام ، و (3) تعطى فيتامين هـ يوميا 1 ملى (50 مجم/كجم) عن طريق انبوبة التغذية بالفم ثم تمارس السباحة يوميا لمدة ساعة لمدة سبعة أيام منتالية. النتائج: وجدنا أن الضغط الجسمى و العصبى الناتج عن ممارسة السباحة من غير سابق تمرين لمدة ساعة كاملة على مدى سبعة أيام متتالية أد ى الى ارتفاع ملحوظ فى مستوى مؤشر ات الالتهاب فى الدم من عامل نخر الورم ألفا، و الانترفيرون جاما و البروتين المتفاعل جيم. كما أن اعطاء فيتامين هـ لمدة سبعة أيام متتالية قبل التعرض

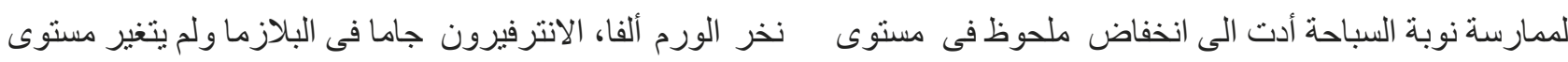
البروتين المتفاعل جيم. تسبب الإجهادالناتج عن ممارسة السباحة الى انخفاض كبير في الوزن النسبي للكلى، و الوزن الكلى للجسم ،

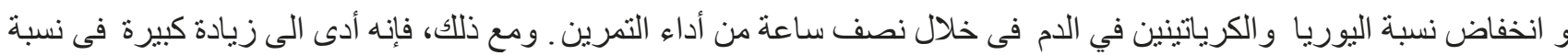
اليوريا الى الكرياتينين الدالة على التعرض الى الجفاف. كما وجدنا أن اعطاء فيتامين هـ أدى الى انخفاض فى نسبة اليوريا الى لى

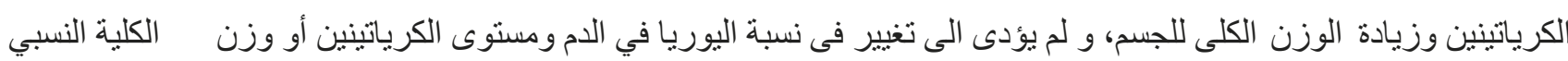

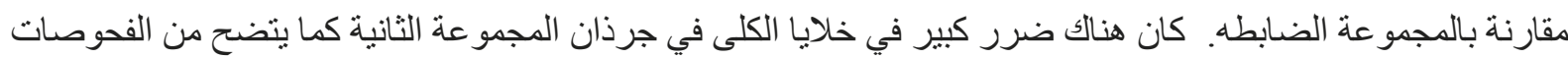

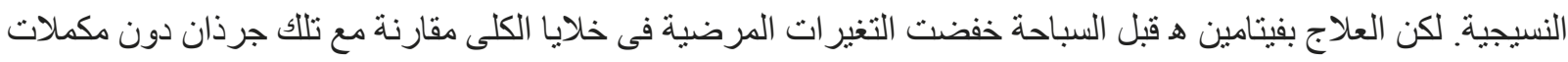

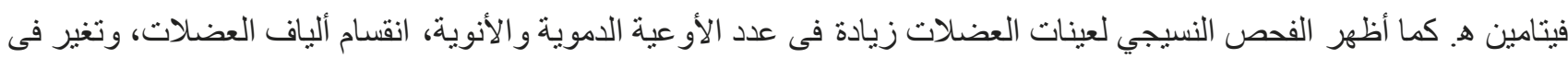
مكان الأنوبة الى موقع مركزي فى الخلية. مكملات فيتامين هـ أدت الى تحسين معظم التغير ات النسيجية التي حدثت في العضلات و. و

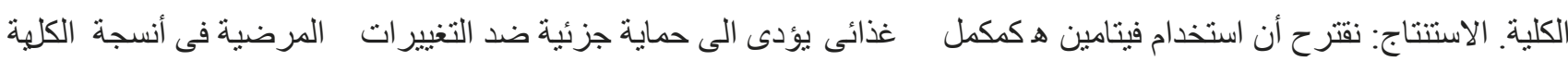

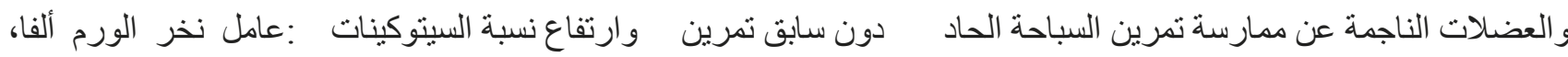
و الانترفيرون جاما. و علاوة على ذلك فان مكملات فيتامين هـ له دور واعد في منع الجفاف و الضرر الكلوى المحتمل من ممارسة النشاط الرياضى الحاد. 